Harvard Data Science Review • Issue 3.3, Summer 2021

\title{
Two Regimes of Prison Data Collection
}

Kaneesha R. Johnson ${ }^{1}$

${ }^{1}$ Department of Government, Harvard University, Cambridge, Massachusetts, United States of America

Published on: Jul 30, 2021

DOI: $\underline{\text { https://doi.org/10.1162/99608f92.72825001 }}$

License: Creative Commons Attribution 4.0 International License (CC-BY 4.0). 
Column Editors' Note: From risk assessment scores to facial recognition, data-driven tools have become central to policing and punishment over the last century, and they are also urgent sites of struggle and contestation. Presumptions about criminality — and the data collected in the name of tracking criminal behavior -prove to be deeply intertwined with other kinds of data sets, from census and municipal records to that of insurance and mortgage companies. In this column, political scientist and historian Kaneesha Johnson traces the changing form and content of prison data and questions how and why different communities and institutions collect the data they do. In particular, she compares the data gathered about crime and incarceration by the U.S. government with data gathered by incarcerated people and their communities in part to show that what we measure, collect, and count is always a reflection of the world we are trying to create.

Keywords: prison data, community data

The first records of state organized data collections of prisons and incarcerated people in the United States began with the 1850 census and remains one of the most widely cited sources of adult prison data. The first iteration gathered a few basic points of information; number of people incarcerated, geography, race, age, nativity, and sex. Although seemingly straightforward, the questions, and the people who crafted them, established a statistical lock-in of how to understand the prison system and those held within it.

The content of data that is gathered—what is being asked and recorded—and the initial intentions driving data gathering often dictate the parameters of our understanding (Nobles, 2000). For instance, the Bureau of Justice Statistics (BJS) Survey of Prison Inmates gathers data pertaining to the status of a sentence: awaiting trial, awaiting sentencing, awaiting revocation hearing, or serving sentence. This gives us information for understanding where people are in the system and identifying those who are being held for pretrial detention, and for how long. Whereas a survey conducted by incarcerated people at the Louisiana State Penitentiary, who have a more personal understanding of the sentencing process, in addition to counting sentence lengths also gathers data on the perception and quality of legal representation, thus moving beyond a story of who is where and giving us the necessary details of why people are held up in the system, reasons often beyond an individual's control.

Contrasting the history and content of national state-sourced prison data with data collected by those most acutely impacted by the prison invites a new perspective of the role of the former. State prison data is primarily concerned with counting and painting a picture of who occupies a system; what they did, what they look like, and what are some select individual behaviors. It rests on an assumption that everything is best known from afar - especially by those who receive training from Western universities, whose job it is to produce 'valid' knowledge (Mignolo, 2011), whereas community data collection grapples with the experience of living within the prison, the conditions that are faced, institutional failures, and the ripple effect of prisons on the wider 
community. This later form of collection relies on an expertise found not within the ivory tower, but in those proximal to the harm and who believe that experience itself is valuable knowledge.

\section{State Collected Prison Data}

The leading national state-sourced corrections data collection has historically been the U. S. Census Bureau, the National Prisoner Statistics (NPS), and the BJS, all of which continue to be relied upon as some of the main authorities for national state-sourced data. $\underline{1}$ These data serve to both count the prison population and as a foundation for national policy (U. S. Census Bureau, 2020). Since the census' 1850 inception, despite some year-to-year variations on the specific questions included in the decennial census collection, the general categories of the questions have remained unambiguously similar to the initial years.

There are two somewhat contradictory points on the importance of data infrastructure establishment. First, it is important to have some kind of stable and over-time measure of a system, hence, reproducing questions is a necessary practice to understand longitudinal change. Second, data collection has important epistemological value - what is asked and recorded in the beginning becomes increasingly important over time, not because of measurement or comparison purposes, but because of the ways in which it shapes our understanding of the system. In reference to prison data, the data has power to limit our perception of who serves time in prisons and the reasons why they are there.

Tables 1-3 provide an overview of the type of information collected by the three state prison data collection bodies. Each table provides information on three broad categories: prison and sentence related, demographics, and other (mostly socioeconomic information)

\section{Visit the web version of this article to view interactive content.}

The most striking takeaway from Table 1 is that the questions asked in the 2010 census are identical to the questions asked in the 1850 census: number incarcerated, location of prison, type of prison, sex, race, and age. Second, although there is a level of statistical inertia, there is also expansion at specific points. Beginning in the 1880s, the census intensified its data collection of incarcerated individuals, collecting information pertaining to their occupation, formal schooling, health, and citizenship. The 1850 census had made imprisonment something to do with locality and race. Between 1890 and 1980, the census made connections between incarceration and individual factors: health, income, literacy, occupation, and so on.

In 1926, 76 years after the census began to gather prison data, the NPS joined the practice. Despite being moved to various departments over the duration of its existence, the content of the data has remained fairly constant, and mirrors the information we observe in the census (see Table 2). 
Table 2. Questions related to prisons on the national prisoner statistics 1926-2018.

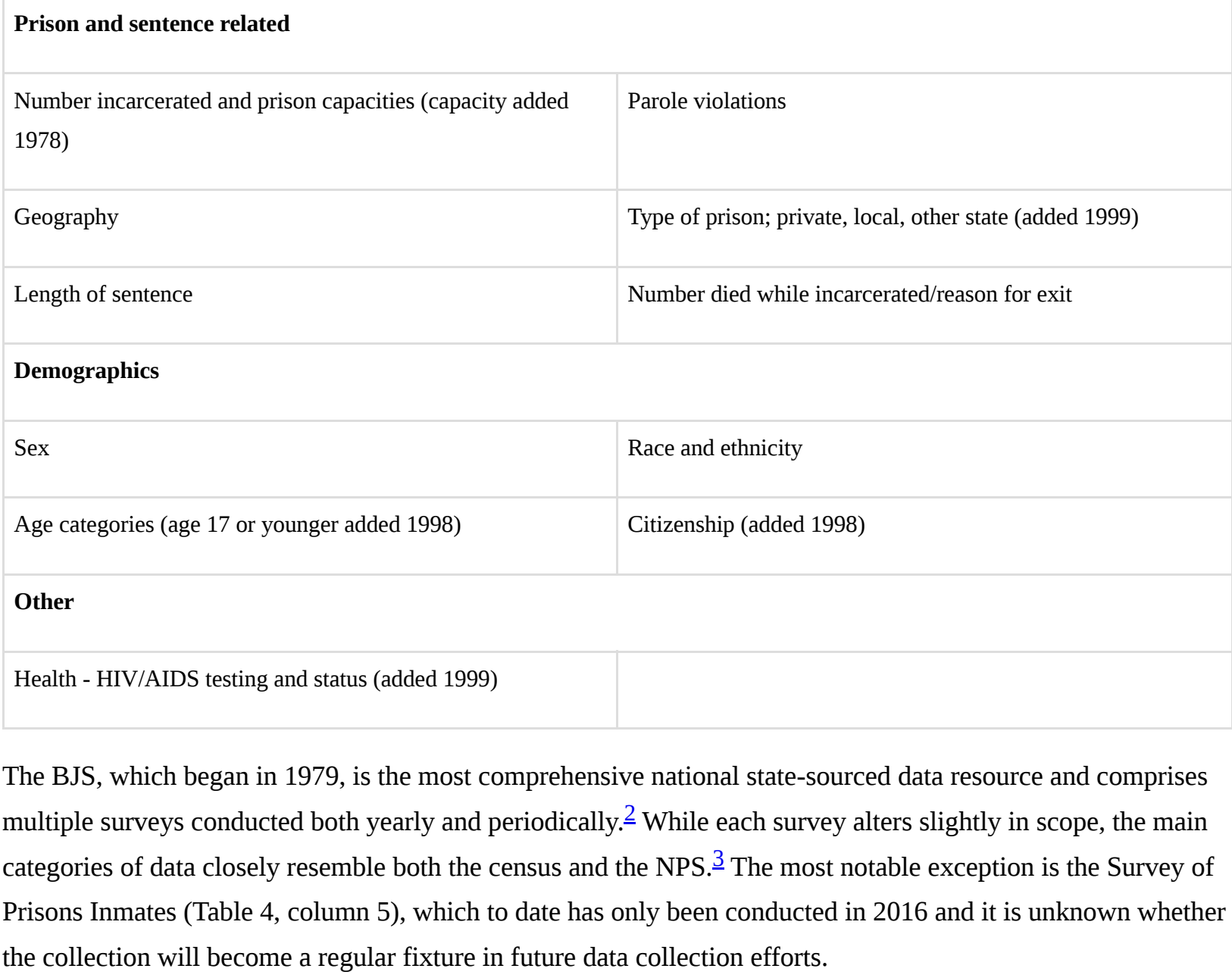

Table 3. Bureau of Justice Statistics “inmate” question categories.

\begin{tabular}{|l|l|l|l|l|}
\hline $\begin{array}{l}\text { Annual Survey of } \\
\text { Jails }\end{array}$ & $\begin{array}{l}\text { National Inmate } \\
\text { Survey }\end{array}$ & $\begin{array}{l}\text { Report of Inmate } \\
\text { Under Sentence of } \\
\text { Death }\end{array}$ & $\begin{array}{l}\text { Survey of Inmates in } \\
\text { Local Jails }\end{array}$ & $\begin{array}{l}\text { Survey of Prison } \\
\text { Inmates }\end{array}$ \\
\hline Prison and sentence related & Year & Year & Year & Year \\
\hline Year & Number incarcerated & Number incarcerated & Number incarcerated \\
\hline $\begin{array}{l}\text { Number incarcerated } \\
\text { and capacity }\end{array}$ & Geography & Geography & Geography & Geography \\
\hline Geography & & & \\
\hline
\end{tabular}




\begin{tabular}{|c|c|c|c|c|}
\hline & Type of prison & Type of prison & Type of prison & Type of prison \\
\hline & Length of sentence & & Length of sentence & Length of sentence \\
\hline & Prior admission & Prior prison admission & Prior prison admission & $\begin{array}{l}\text { Prior prison admission } \\
\text { and criminal history }\end{array}$ \\
\hline Status of sentence & & $\begin{array}{l}\text { Status of sentence and } \\
\text { method of execution }\end{array}$ & & Status of sentence \\
\hline \multirow[t]{5}{*}{ Type of offense } & & & & Type of offense \\
\hline & & $\begin{array}{l}\text { Date of arrest and } \\
\text { sentence }\end{array}$ & & $\begin{array}{l}\text { Date of arrest and } \\
\text { sentence }\end{array}$ \\
\hline & & Reason for removal & & \\
\hline & & & Sentence fees & Sentence fees \\
\hline & & & & Information on victim \\
\hline \multicolumn{5}{|l|}{ Demographics } \\
\hline Sex & Sex & Sex & Sex & Sex \\
\hline Race/color/ethnicity & Race/color/ethnicity & Race/color/ethnicity & Race/color/ethnicity & Race/color/ethnicity \\
\hline \multirow[t]{4}{*}{ Age category } & Age & Age & Age & Age \\
\hline & Sexual orientation & & & \\
\hline & & & & Citizenry \\
\hline & & & & Nativity \\
\hline \multicolumn{5}{|l|}{ Other } \\
\hline & $\begin{array}{l}\text { Victim of sexual } \\
\text { assault }\end{array}$ & & & \\
\hline & & Marital status & $\begin{array}{l}\text { Marital status and } \\
\text { children }\end{array}$ & $\begin{array}{l}\text { Marital status and } \\
\text { children and contact } \\
\text { with them }\end{array}$ \\
\hline
\end{tabular}




\begin{tabular}{|l|l|l|l|}
\hline & Schooling & $\begin{array}{l}\text { Schooling and } \\
\text { employment }\end{array}$ & $\begin{array}{l}\text { Schooling, } \\
\text { employment, and } \\
\text { income (including } \\
\text { work in prison) }\end{array}$ \\
\hline & & & Health \\
\hline & & $\begin{array}{l}\text { Health } \\
\text { (including parent } \\
\text { information) }\end{array}$ & Drug and alcohol use \\
\hline
\end{tabular}

The information collected by each agency adheres to similar categories. All collect general prison and sentencing information: year, number incarcerated, location of prison, type of prison, sentence length, and reason for exit. Demographic information remains consistent; sex, race, age. Socioeconomic information includes health, years of formal schooling, employment and income prior to incarceration, drug and alcohol use, and marital status.

What exactly is the problem with relying on standards that were established in data collections of the late 19th century? For one thing, these data collections and their reproduction of 19th-century questions do not address the evolution in our understanding of the causes and consequences of the prison system, most notably the shifting from personal behaviors and traits to more structural factors-including the changing political landscape (Owens \& Smith, 2012), reactions to civil rights gains (Weaver, 2007), the public's willingness to ascribe to tough-on-crime policies (Enns, 2014), and the social and economic interests in maintaining and expanding the prison industrial complex (Carceral Tech Resistance Network 2020; CR10 Publications Collective 2008; Parenti, 2000).

The widening scope of prison data collection also emerged as White supremacy was mutating under a new system. No longer permitted to delegate Black people to a bottom-class citizenry through the institution of slavery, more innovative techniques had to be developed to explain why a delegation must be made. Those first iterations of census prison data collection coincided with a revival of racial science around the globe (Riegel, 1933; Shaler, 1890), which eventually found its way to the practice of crime and prison data collection (DuBois, 1897; Floyd, 2006; Hoffman, 1896). As highlighted by Khalil Muhammad, Francis A. Walker, the superintendent of the 1870 census and lead of the 1880 census, played an important role in elevating Frederick Hoffman's Race Traits and Tendencies of the American Negro, one of the first book-length accounts of Black criminality in the United States, which relied heavily on the Eleventh Census of the United States in 1890 data to come to conclusions of Aryan superiority (Muhammad, 2010).

Walter F. Willcox, also a central figure in the development of the census, in 1899 wrote of the "criminal tendencies” of the African American, "from all the evidence obtainable it seems clear that Southern agriculture 
is become increasingly diversified, and is demanding and receiving a constantly increasing amount of industry, energy, and intelligence,- - characteristics which the whites more generally possess or more readily develop" (Willcox, 1899, p. 11). He continues to describe the "lower class African American" as "styled potentially criminal” (p. 14), and that the only way for White people to govern Black people is not through personal loyalty, as he believed existed during slavery, but through an increasing amount of force and punishment.

The continual fabrication of data as an 'objective' measure of criminality among Black Americans ultimately gave legitimacy to systematic punishment, because 'they are the ones who commit the crimes,' a sentiment that has persisted with such fierce intensity that it remains exceedingly difficult to detach from. It also mutes the fact that criminality is a constructed phenomenon, rather than an immutable character trait, inducing a moral panic to legitimize the expansion of the carceral state and the punishment of certain groups (Gilmore, 1999; Hall, 1978).

\section{Community Sourced Prison Data}

When seeking answers using data, we are confined to what the data allows us to ask, and what we ask can often be restricted to the biases of the person, or institution, who decided what is important to ask from the outset. What questions should we be asking to gain a better understanding of the world through data collection? Where should we look for guidance in formulating those questions? Community-sourced data collections are likely our best bet. People who have lived within or with the prison system add meaning to otherwise arbitrary distinctions and question assumptions made by those who have not; should we think of crime as a cause or an effect? What are the physical conditions of the prisons? How has prison impacted your mental and physical health? What constitutes a long prison sentence?

In 1976, in an attempt to fill the knowledge gap, the editors of the Angolite, a newspaper founded in 1942 and produced by incarcerated people in the infamous Louisiana State Penitentiary (LSP), also known as Angola prison, conducted a prison-wide study to better understand the state of the "longtermer," which they use to describe those who had been confined for at least 10 years in a single stretch. Their mission:

“Why do they keep them locked up so long, when they let others out?" Is a question often wondered about by many of us. Four months ago THE ANGOLITE decided to try to find an answer to that question. And we tried. Unfortunately, nobody had information as to how many "old-timers" are confined, who they are, to any other data pertinent to that group of prisoners. We were faced with the choice of either securing the data ourselves or doing like everyone else - forget it. We decided to do it, see what we could dredge up. (The Angolite Editors, 1976)

The study took 2 months to complete and included a comprehensive survey of the majority of the longtermer population of the LSP. While the study has some components that reflect the state-sourced data collection, including basic demographic and sentencing information, there are a number of questions that unveil some 
critical components of the prison commonly overlooked by national data collections. Figure 1 shows the section of the study that looks at the assistance received from longtermers.

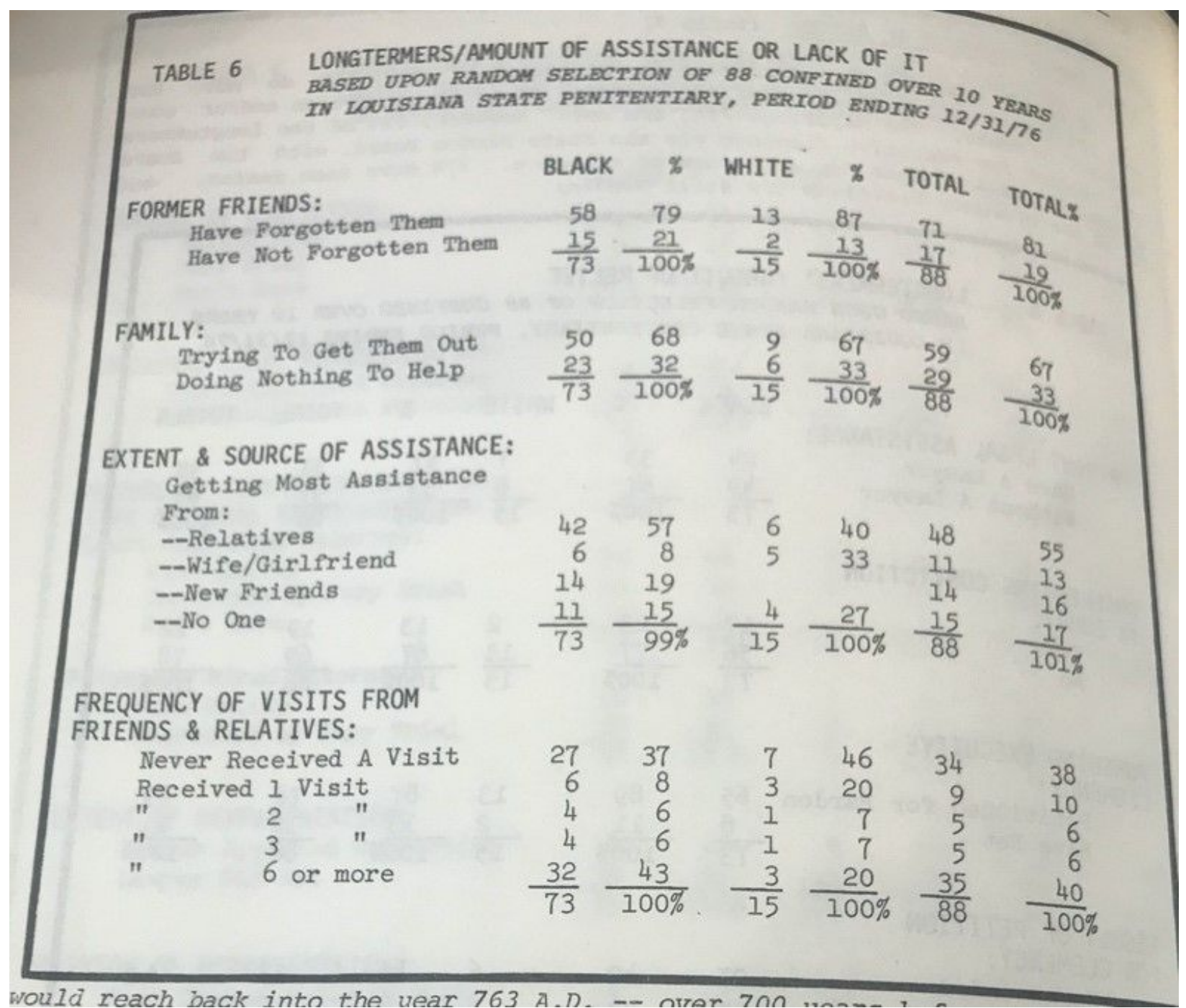

Figure 1. The Angolite "longtermers" study, amount of assistance or lack of it, Beinecke Rare Book and Manuscript Library, Yale.

The longtermers survey asks 88 randomly selected men confined for more than 10 years whether their former friends have forgotten them ( $81 \%$ yes), whether their families are actively trying to get them out (61\% yes), and where their main source of assistance is derived from: relatives (55\%), partner (13\%), new friends (17\%), or no one (17\%). These numbers demonstrate far more than a counting game of who is incarcerated. It shows both the devastating effect that incarceration has on friendships- $81 \%$ of longtermers believed that their former friends had forgotten them, and 38\% percent of them had never received a visit from a friend or relative -as well as the staggering amount of time and resources families spend trying to get their loved ones out of the prison $-67 \%$ believed that their families were trying to get them out after at least 10 years of imprisonment. The study also reveals shocking numbers surrounding the legal representation of longtermers. 
Only 26\% believed that their lawyer tried to help them and 93\% did not have the original attorney that handled their case.

The Angolite longtermers study is just one example of how data collection can look entirely different when taking an alternate position to the state. The National Campaign to Stop Control Unit Prisons (NCSCUP) was founded in 1994 by people living inside and outside of prison walls to "engage in collecting data, education, fostering public awareness, and acting to put an end to human rights abuses that occur daily in control units” (NCSCUP, 1995a). The campaign gathered a huge amount of information by reaching out directly to people incarcerated in control units—-defined as units that "disable prisoners through spiritual, psychological, and/or physical breakdown” (NCSCUP, 1995a) — and documented the conditions they were subjected to. Figure 2 shows a copy of a questionnaire included in their 1995 National Campaign to Stop Control Unit Prisons How to Packet (NCSCUP, 1995b).

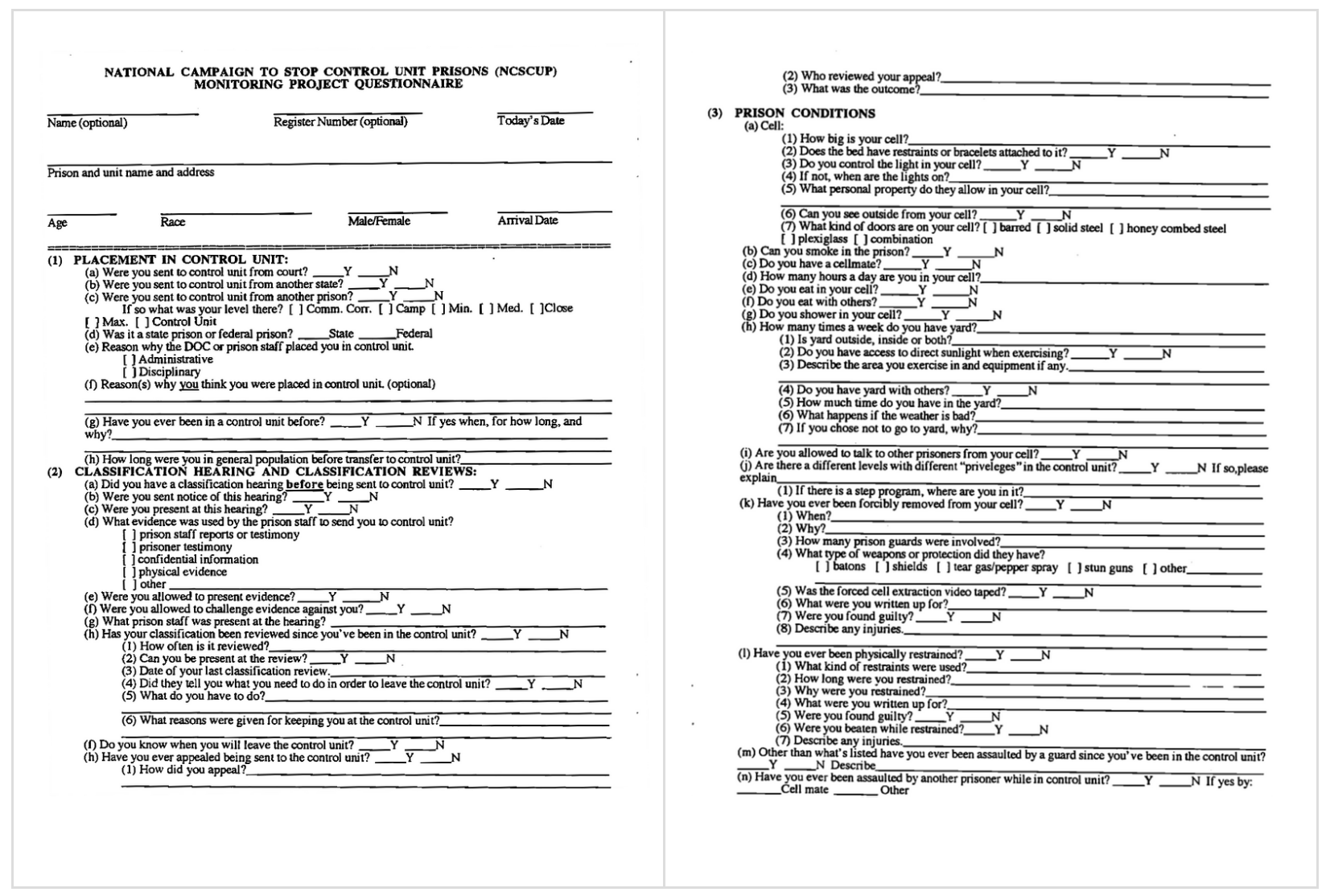




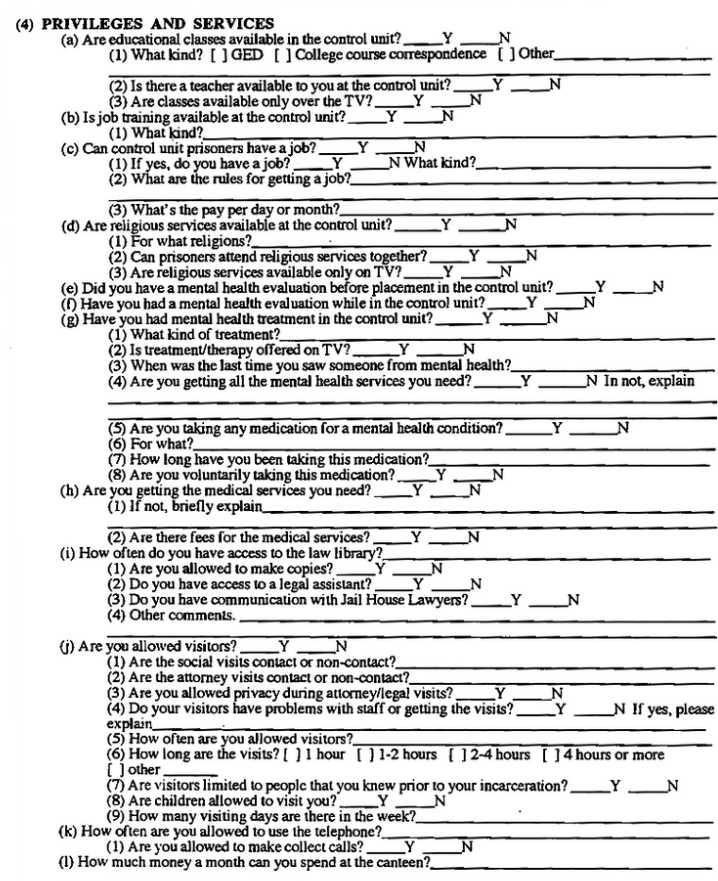

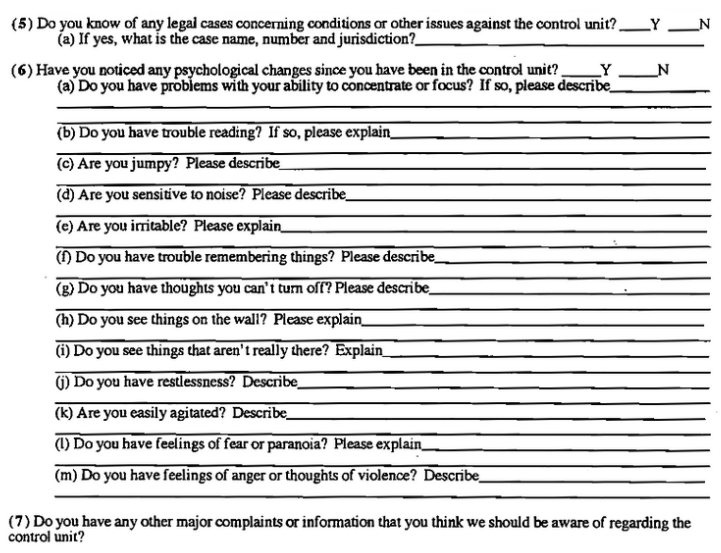

(8) Please list the narne, address and phone number of anyone (family member, friend, attorney) you think may
be interested the monitoring the control unit, .

Thank you for your time.

PLEASE RETURN QUESTIONNAIRE TO:

Figure 2. Questionnaire from National Campaign to Stop Control Unit Prisons How to Packet, 1995, Freedom Archives.

Similar to the Angolite longtermers survey, the NCSCUP gathered basic demographic information and information in four broad categories: placement in control units, classification hearings and classification reviews, prison conditions, and privileges and services. In each section, respondents were asked to provide information on topics that, for those looking from a distance, (1) could be assumed to be the case, such as asking if the person has access to legal assistance, or (2) would have not considered asking: "Can you see outside from your cell?," "Do you have access to direct sunlight?," "Do you have thoughts you can't turn off?” The NCSCUP goes beyond individual traits of the respondent and questions the way the system functions: "Were you allowed to present evidence [in your classification hearing]?," "Were you able to challenge evidence against you [in your classification hearing]?”; thus recognizing that the system itself, rather than character traits or individual actions, often dictates outcomes.

Beyond a comprehensive understanding, data collected by the NCSCUP were used in a larger campaign to "monitor conditions in control prison units across the country, and seek to resist, and eventually abolish, all control unit prisons” (Ikuta, 1995). The NCSCUP, aided by the 1995 survey, had a number of early wins, including the release of four political prisoners being held in control units.

The juxtaposition of the two regimes of prison data collection reveal that community data gathering not only results in a more complete understanding of the prison system, it allows for more meaningful interventions in 
response to harms created by the system. Prison data collection may have been born from Enlightenment-era projects of state-based data collection and racial science, but we are no longer bound by those limitations in understanding. What might the future of prison data consumption look like? It involves those of us who have relied too extensively on state data to interrogate who established the data infrastructure and why they were motivated to do so. It requires us to be diligent in seeking out the geneses of data so that we do not unknowingly accept and reproduce potentially misguided conclusions. By relying uncritically on state-sourced data that originated with an agenda of proving racial inferiority, we risk embedding the assumptions behind those claims in future research.

This is not to say that the conclusions we come to, by using state data, are always going to reproduce biases. It is also not to say that the questions asked in state prison data collections are inherently bad; indeed, movements have been successful in repurposing them to help give evidence of deeply unequal outcomes and to change carceral policies. But our reliance on state data has precluded much of our ability to see the whole picture. What might our research, policies, and understanding of the world look like if we move from a belief that the trajectory of a person's life after prison is not determined by the years of formal education they have received, but whether they lived for years in a system that did not give them access to direct sunlight?

\section{Disclosure Statement}

Kaneesha R. Johnson has no financial or non-financial disclosures to share for this article.

\section{References}

Angolite Editors. (March/April 1977). The Longtermers Study. The Angolite.

Carceral Tech Resistance Network. (2020). Why. https://static1.squarespace.com/static/5d7edafcd15c7f734412daf2/t/5e842016a28b9416638fd698/15857172827 76/documentation+\%2F+2020-03-30+\%2F+why

CR10 Publications Collective. (2008). Abolition now! : Ten years of strategy and struggle against the prison industrial complex. Oakland, CA: AK Press.

DuBois, W. E. B. (1897). Race traits and tendencies of the American Negro by Frederick L. Hoffman. The Annals of the American Academy of Political and Social Science, 9(1), 127-133.

https://doi.org/10.1177/000271629700900108

Enns, P. K. (2014). The public's increasing punitiveness and its influence on mass incarceration in the United States. The American Journal of Political Science, 58(4), 857-872. https://doi.org/10.1111/ajps.12098 
Floyd, J. (2006). Dislocations of the self: Eliza Farnham at Sing Sing Prison. Journal of American

Studies, 40(2), 311-325. https://doi.org/10.1017/S0021875806001393

Gilmore, R. Wilson. (1999). Globalisation and US prison growth: From military Keynesianism to postKeynesian militarism. Race \& Class, 40(2-3), 171-188. https://doi.org/10.1177/030639689904000212

Hall, S. (1978). Policing the crisis: Mugging, the state, and law and order (Critical Social Studies). Macmillan.

Hoffman, F. (1896). Race traits and tendencies of the American Negro. Publications of the American Economic Association, 11(1-3). Published for the American Economic Association by Macmillan.

Ikuta, N. (1995, October 21). Committee to End the Marion Lockdown [Presentation at Fall program]. http://people.umass.edu/ kastor/fallprogram/fall-ikuta.html

Mignolo, W. D. (2011). The darker side of Western modernity: Global futures, decolonial options. Duke University Press.

Muhammad, K. (2010). The condemnation of blackness: Race, crime, and the making of modern urban America. Harvard University Press.

National Campaign to Stop Control Unit Prisons. (1995a).

http://freedomarchives.org/Documents/Finder/DOC4 scans/4.national.campaign.stop.brochure.1995.pdf

National Campaign to Stop Control Unit Prisons. (1995b). National Campaign to Stop Control Unit Prisons how to packet. National Campaign to Stop Control Unit Prisons http://freedomarchives.org/Documents/Finder/DOC4 scans/4.NCSCUP.how.to.pdf

Nobles, M. (2000). Shades of citizenship: Race and the census in modern politics. Stanford University Press.

Owens, M. L., \& Smith, A. R. (2012). "Deviants” and democracy: Punitive policy designs and the social rights of felons as citizens. American Politics Research, 40(3), 531-567. https://doi.org/10.1177/1532673X11432880

Parenti, C. (2000). Crime as social control. Social Justice, 27(3), 43-50.

Riegel, R. E. (1933). The introduction of phrenology to the United States. The American Historical Review, 39(1), 73-78. https://doi.org/10.1086/ahr/39.1.73

Shaler, N. (1890, July). Science and the African problem. Atlantic Monthly. https://www.theatlantic.com/magazine/archive/1890/07/science-and-the-african-problem/523647/

U. S. Census Bureau. (2020). 2020 census residence criteria and residence situations. https://www2.census.gov/programs-surveys/decennial/2020/program-management/memo-series/2020-memo2018 04-appendix.pdf 
Weaver, V. M. (2007). Frontlash: Race and the development of punitive crime policy. Studies in American Political Development, 21(2), 230-265. https://doi.org/10.1017/S0898588X07000211

Willcox, W. F., \& African American Pamphlet Collection. (1899). Negro criminality. Geo. H. Ellis, Printer. Library of Congress. https://www.loc.gov/item/06031900/

(C2021 Kaneesha R. Johnson. This article is licensed under a Creative Commons Attribution (CC BY 4.0) International license, except where otherwise indicated with respect to particular material included in the article.

\section{Footnotes}

1. Due to the localized nature of the prison system in the United States, there are numerous data collections occurring at the state and local levels, which often differ dramatically in content. $\bullet$

2. Current active surveys for the adult incarcerated population are the Annual Survey of Jails, Census of Jail Inmates, National Inmate Survey (as funding permits), National Prisoner Statistics Programs (moved under the jurisdiction of the Bureau of Justice Statistics from 1979), Report of Inmate Under Sentence of Death, Survey of Inmates in Local Jails, and Survey of Prison Inmates. $€$

3. An exception is the National Survey of Youth in Custody, which gathers extensive data in accordance with the Prison Rape Elimination Act of 2003 as specified in the act. $\leftrightarrows$ 